\title{
Natural Resources, Energy and Sustainable Development
}

\author{
Ademola Emmanuel Oluniyi \\ Peace and Conflict Studies \\ University of Ibadan, Ibadan, Oyo state Nigeria \\ E-mail:niyi_ademol@yahoo.com
}

\section{Doi:10.5901/mjss.2014.v5n3p643}

\begin{abstract}
In its origin, the word resources mean life. Its root in the Latin word surgene, which represents the image of a spring that continually rises from ground. Like a spring, therefore, resources rise again and again, even if it has repeatedly been used and consumed. The use of natural resources however, rest on the power of self regeneration and call attention to the prodigious creativity of man. Natural resources can be classified into two, broad categories: flow or renewable and stock or non renewable. The flow resources are those that can be naturally renewed within short time, such as plant, water and animals. The stocks resources are those with fixed supply includes mineral oil and land. All are meant for the use of man and his sustenance. The process of renewal the resources have been found on the activity of human beings in the development of their environment. This process of renewal described the transition of resources from its natural state through the period of its first contact with man to its final stage. Men and their activities with the natural environment have however become conflicting. There have been problems and conflicts all over the world as a result of over utilization of the natural resources which has now created conflicts between men and environment and between man and man. Some of these problems arise from: water pollution, acid rain, deforestation, loss of natural animals, plant speeches and gas flaring. Thus has now called for natural resources, energy sustainable development.
\end{abstract}

Keyword: Natural Resources, Energy and Sustainable Development

\section{Introduction}

In its origin, the world resource means life as vandama (1995) noted, its root is the Latin word surgere, which presents the image of a spring that continually rises from ground. Like a spring, therefore, a resource "rises again and again, even if it has repeatedly been used and consumed." Specifically, there are limits to our natural resources, which are the various substance and energy we need in order to survive. Some resources, such as the plants we harvest for food and shelter, can regenerate over time, but only if we are careful not to use them up too quickly or destructively. For the purpose of this discourse, I will define natural resources as all non-artificial products situated on or beneath the soil, which can be extracted, harvested or used, and whose extraction, harvest or usage generates income or services and other functional purposes in benefiting mankind. Included on this are land, solid minerals, petroleum, water, water resources and animal stock.

Also are other resources that are not covered by this broad definition for example, solar energy and wind. Apart from the fact that their impact are also noticed they have hardly be linked to violent conflicts, especially in developing societies like those first mentioned. Also left out of the definition are human beings and the exclusion which can be explained on the grounds that human beings exploiting these other resources are the very subject being discussed "natural resources energy and sustainable development." Judith Rees, (1994) in her classification of natural resources classifies it into two broad categories as: flow or renewable and stock or non renewable. The flow resources according to her are those resources that can be naturally renewed within short time, such as plants, water and animal. The process of renewal is either on human activity or on natural processes. The stock resources are those with fixed supply which include solid minerals, oil and land. What seems broadly acceptable to all is the fact that natural resources constitutes a functional relationship between man's want, his abilities, and his appraisal of his environment (Simmons, 1974). Man in his attempt to transform the natural resources to use, undergo different processes starting from its first contact to its final stage. In the process, man actions become conflicting either with environment or between men. This is particularly important in appreciating the politics that often surround the management of natural resources, as every stage of this process contains ingredients of conflict.

To this end, it has become very imperative for us to understand our interaction with the environment which we 
ourselves are part. Firstly, we should realize that we depend upon our environment for air, water, food, shelter, and everything else essential for living. Secondly, our actions modify our environment, weather we intend them to do so or not. This is because many of our actions have brought us beneficial changes, such as longer lifespan, material wealth, mobility, and leisure time. However, numerous others have spawned undesirable changes from air and water pollution to soil erosion to species extinction that compromise human well-being and can threaten human life.

\subsection{Natural Resources Study}

Scholars have identified four approaches in the study of natural resources process; first is the economic approach, which follow the basic economic principle of supply and demand. The focus on this is on how societies match supply of resources to the demand for them. A second approach adopts an ethical dimension, judging how man ought to use biosphere; as every element of nature is seen as having economic, cultural, or aesthetic value. The third take a behavioural approach, looking at socio cultural traits and psychological impulses that cause different societies to make use of its resources in different ways. The final approach is ecological, seeing each resources process as a set of interactions between the biotic and abiotic component of the biosphere.

It operates on the assumption that man's manipulation of these systems has repercussions in the natural environment, and there are limit that should not be crossed without causing serious imbalance in nature (Simmons, 1974). On the whole, implicit in the term natural resources is man's attempt to prioritize his surrounding and environment. Ciriacy-Wantrup (1994) notes that the, 'concept of resources' presupposes that a 'planning agent' is appraising the usefulness of his environment for the purpose of obtaining a certain end. Also in line with the position of Judith contends that before any element can be classified as resources, two basic preconditions must be satisfied: first, the knowledge and technical skills must exit to allow for its extraction and utilization; and second there must be a demand for the materials or service produced. The contention therefore is that, it is human ability and need that create resources value and not the mere physical presence. Erich (1933) puts this functional dimension succinctly when he argues that neither the environment nor parts of it are resources until they are, or are considered to be, capable of satisfying human needs. In this regard, resources are an expression of appraisal and are thus entirely subjective.

\subsection{Africa and the Natural Resources Tragedy}

With the event that followed the cold war era, more prominence has been given to the role of resources, resources exploitation, management and environment as factors shaping international relations. As a result of this more attention has been base on issues that transcend state-centric notion of sovereignty and security and now facing the reality of global economic and ecological resources. Simply stated, there has been such an intense struggle within and between the states and man for the control, exploitation, manipulation and access to ecological resources. For example, many conflicts had occurred while wars have been fought over the possession, acquisition or control of vital natural resources like, water, arable land, gold, silver, diamonds, copper and petroleum. Resources conflict has become more prominent in the post cold war era that, many conflicts as at late 90's in African countries like Angola, Congo, Liberia, Sierra Leone, Somalia, Sudan and Nigeria were driven largely by competition over the control of critical resources of vital materials. As was true in the past, conflict over resources remain a significant feature of the world security environment (Klare, 2001).

Africa continent more than other continents has been mostly affected by the high increase in demand for natural resources process, exploitation and exploration. It is obvious and no doubt, that half of the world's mineral dependent states are concentrated in Sub-Sahara Africa; and that most of these African Countries today derive their main revenue from the exploration and production of these mineral resources. For example, from the oil field of the Niger Delta region in Nigeria, to the diamond and copper fields of Sierra Leone, Angola and Liberia to the rich mineral deposits of Great lake region, to the mountain ranges plain and tourist havens of East African Countries; the continent of Africa is undoubtedly blessed. From these blessing however, much sorrow has followed. (Dare, 2001; Earnest, 2007).

The high rate in resources conflict and share of surplus that come out of it has attained such prominent position in African continent because of four main factors;

- The high global demand for energy resources notably oil, which encourage foreign transnational corporations to exploit, the internal weakness of internal resources governance in African oil producing states and consequently interfere in their domestic politics;

- The high rents that accrue from the resources, which in diverse ways can be linked to corruption and greed on the part of the ruling elites of these countries vis-a-vis community, which had heightening the expectations of 
local population in oil producing communities,

- And lastly, the changing nature of politics, which has increased awareness on the part of civil society for accountable governance with the effects of globalization which raised a new set of considerations in the nature of a global response to energy (Abiodun, 2007).

One can of course argue that current resurgence of conflict over resources has nothing than competition over control of valuable oil supplies and pipeline routes which has occurred as a result of demand for oil growing and many older sources of supply (such as those in the United States, Mexico and China) in decline, the pressure on remaining supplies- notably those in Persian Gulf area, the Caspian sea Basin, South America and African is growing over more intense. That many analysts believe that competition for oil was factor in the 1991 Persian Gulf conflict and the 2003 invasion of Iraq. Several factors by the scholars are underline for increase frequency and intensity on resource conflict in the $21^{\text {st }}$ century as; Economic globalization, unsustainable consumption, population growth and economic warfare in poor and development countries. These many scholars have attested to the link between environment and conflict proponents of the link between environment and conflict; focus on ways in which struggles over shrinking environmental resources either as a result of overuse or misuse or degradation of environment led to stresses which triggers conflict.

Homer-Dixon, (1994) for example, notes that, often scarcities of critical resources can lead to mass violence in several part of world. Similarly, Hudson (1996) points out that fundamental cause of resources depletion and degradation is that human beings consume resources faster than they can replace. He then went further to identify three types of this environmental scarcity namely:

- Supply induced scarcity which cause by degradation and depletion of environment.

- Demand induced scarcity which could be the result of population growth.

- Structural scarcity as a consequence on unequal distribution of resources within and between the communities and states.

Though, African states are well endowed with abundance of these natural resources, yet they lie at the bottom ladder in comparative statistics on the human development. Although, some countries like Botswana and South Africa, have shown ample evidences that mineral wealth can be turned into concrete development benefit if properly managed. That is to say that; these natural resources are not necessarily a developmental trap, and if it is properly managed and revenues are equitably shared these endowment could be truly be a blessing rather than a curse. The reverse however, has been the case in most of African state and especially Nigeria nation- state. Nigeria, Sub Sahara Africa's largest oil producer is a classical illustration of "natural resources as developmental trap". Rich in proven resources approximately 30 billion barrels of oil and having earned an estimated $\$ 340$ billion over the past years, Nigeria's oil exports rank only behind Saudi Arabia, Venezuela, Iran and United Emirates. Her oil dependence accounts for over 83 percent of export earning and approximately 40 percent of GDP (Philips, 1991; Soremekun and Obi 1993; Olomola 1994; Onosode, 2003 Imobigbe 2004).

Despite all these, Nigerian oil economy has remained largely underdeveloped and its citizens particularly those in the oil and gas producing communities are impoverished with their socio-economic status very low compared to their proximity to oil exploration. The reverberation from these politics has influenced oil related conflicts in the continent. The extent of dependence of African states on oil revenue has further increase their vulnerability to wider global considerations. Three aspects of these are particularly important: the first involves the complexities that arose from the high degree of external involvement in the prospecting, production and marketing of oil in Africa. The extensive capital and technological skills required for prospecting and processing oil are often beyond the capacity of most oil producing African countries thus necessitating the involvement of foreign transnational companies. Furthermore, the fact that oil discoveries in some of these countries occurred during the colonial period meant that local input had initially been almost nonexistent. As a result, by the time local entrepreneurs gained inroad, the foreign companies had made significant headway in exploration and marketing of oil while the shares of surplus of oil become the problem within and between the resource communities (African Research Bulleting, 1994).

\subsection{Resource Violent in Nigeria}

However, in Nigeria, it is noted that states are often guilty of not managing the natural resources to the best interest of their people, either by allowing exploitation by specific classes and foreign elites or forcefully controlling access to resources by means of the military or bureaucracy. In Nigeria for example, there are two issues that serve as basis for resource based violence. These are natural resources and poverty. Resource has played a major role in generating violent conflict in the oil bearing communities. There is no doubt that oil has given rise to vertical conflicts between the 
state and society or between the dominant and subordinate regions, classes and groups in Nigeria, given the pivotal role that oil plays in the power restructuring relation in Nigeria. Set in the context of unaccountable and authoritarian power structures of at least five decades, in which communities from where oil is taken have found themselves on the receiving end of this unequal power relation.

Oil as a resource has played a role in fuelling or sustaining new form of violent between state and non state formations. Ohiorhenruan (1998) in his work stated thus; the sheer magnitude of oil surplus appropriated, internally through the state contributed to an acceleration of the process of class differentiation through the legitimate, illegitimate and illegal appropriation of the oil surplus by various factions of the dominant class. The temporary incumbency of the military and bureaucracy provided an opportunity for acquiring a private fortune and thus a more secure bourgeois base....

For years, Nigeria's oil-rich Southern Delta for example, has been the scene of repeated armed clashes among local residents, dissident groups and military and police. The fighting has claimed many lives and sporadically disrupted the country's main export sector. The unrest has been stocked by popular frustrations over poverty, pollution and heavy handed security tactics. The area "vast oil wealth has barely touched people's lives" noted by the UN Development programmed in July 2006 in its report on human development programmme. Many communities believe that the government, military and foreign companies are ready to neither do anything to ameliorate the degradation which has affected their livelihood nor do anything to enjoy the benefit of oil unless they fight.

Oil production no doubt has a lot of impact on the environment, within and immediate community and the country as a whole (Human Right Watch, 1999). Despite decades of oil production, there is surprising little good quality independent scientific data on the overall long-term effects of hydrocarbon pollution, yet oil-led development has clearly seriously damaged the environment and the livelihood of many of those living in the oil producing communities. Though the oil companies operating in Nigeria maintain that their activities are conducted to the highest environmental standards; but Nigerian environmental laws in most aspects comparable to their international equivalents are poorly enforced.

The framework for oil in Nigeria is set by the Petroleum Act (original Decree No 51 of 1969). Other relevant legislation includes the oil in Navigable Waters Act (Decree No.34 of 1968), the oil pipeline Act (Decree No.31 of 1956), the Associated Gas (rejection) Act of 1979), and Petroleum (Drilling and Production) Regulation of 1969, made under the petroleum Act. From 1988, the Federal Environment Protection Agency Act (Decree No. 58 of 1988) vested the authority to issue standards for water, air, and land quality in a Federal Environment Protection Agency (FEPA), and regulations made by FEPA under the Decree govern environmental standards in the oil and other industries. The Department of petroleum Resources (DPR) has also issued a set of Environment Guidelines and Standards for the Petroleum industry in Nigeria in 1991, which overlap with and in some cases, differ from those issued by FEPA. For the most part, the specific standards set are comparable to those in force in Europe or the United States of America. But while all these are just in paper, the implementation has become problematic. Many oil industries in Nigeria have failed to abide with guidelines on sustainable development. With the entire regulatory framework governing protection of the environment in Nigeria, there is in practice, little enforcement of the requirements for sustainability.

\section{Sustainable Development and Resources Management}

Sustainable development, as a new concept, was first introduced in 1987 in the Brundtland Commission Report or the World Commission on Environment and Development which was a United Nations' initiative to pursue justifiable economic development in light of the rapid deterioration of human environment and natural resources. The commission defined sustainable development as "development that meets the needs of the present without compromising the ability of future generations to meet their own needs." In this reckoning, the challenge then is to find ways that meet the needs of the present generation while keeping in view the needs of future generation. Development may be thought of as the act of making purposeful changes to improve the quality of human life. However, environmental scientists have long pointed out that many forms of development have so degraded the natural environment that they threaten the very improvement for human lives that were intended (Brenna, 2005). Development, if it is to be sustainable, should be environmentally safe, socially and economically equitable. Economic sustainability can be defined as that development strategy which takes into account not only increase in the GDP or GDP per capita but also a conscious effort to minimize the harmful effects of economic activities on the natural resource base.

In line with the concept of sustainable development, this would mean that sustainable development in the economic sense is one that does not reduce the productive base or the productive ability of the future generation as well. Therefore, it encourages the use of resources efficiently so as to ensure profitability and ethical management of ecology. 
The activities of oil exploration in Nigeria however, have gone contrary to this aforementioned assertion; that many of them today have been challenge of double standards. They have been accused of operating in Nigeria, with practice that would never be permitted in North America or Europe. There have been series of problems as; flooding and coastal erosion, sedimentation and siltation, degradation and depletion, noise and light pollution, health problems as well as socio-economic problems in Nigeria over the oil resources exploration (Osolo, 1998).

\section{Oil-Related Environmental Problems in the Oil Communities Nigeria}

The specific environmental effect of oil exploitation on the oil communities is examined in this section in order to determine the extent of the impact on the people's capacities to generate and sustain their means of livelihood. The analysis shows that oil communities in the Niger Delta area of Nigeria facing severe ecological devastation, in other words, that the environmental effect is negative. The oil industry activities that affected the environment of the host communities are examined in greater details.

\subsection{Oil Spillage}

Oil spillage is the most common and controversial of all the environmental impacts of oil exploitation. Constitutional Rights Project (CRP, 1999) defines oil spills as uncontrolled releases of any product relating to oil production including crude oil, chemicals, or waste caused by equipment failure, operation mishaps, human error, or intentional damage to facilities. Oil spillage occurs during the drilling of oil wells and as a result of oil pipelines leakages and during the loading of oil into the tankers (Adewuyi, 2001). Spills are potentially the most devastating on agricultural land and water resources. UNDP (2006) reports that much of the environmental pollution in the oil-producing areas is the result of oil spillage due, essentially, to accidents based on human error and equipment failure. The report finds that a total of 6,817 oil spills occurred between 1976 and 2001, with a loss of approximately three million barrels of oil. More than 70 percent was not recovered. Approximately 6 percent spilled on land, 25 percent on swamps and 69 percent in the offshore environment. Statistics from the Ministry of Petroleum Resources also indicate that between 1976 and 1996, a total of 4,836 incidents resulted in the spillage of at least 2,446,322 barrels (102.7 million U.S gallons) of which an estimated $1,896,930$ barrels (79.7 million U.S gallons) were lost to the environment. The extent of the impact on the study area where oil exploitation is largely offshore can best be imagined. Orubu et al., (2004) share this view when they reported that massive oil spills occurring in the riverine areas have done untold damage to the aquatic ecosystem, particularly in the mangrove swamp forest zone.

An average of one oil spill occurs every week and three oil spills are recorded each month in most of the oilproducing areas of the Niger Delta, in which the proportion lost to the environment is quite disturbing (Awobajo, 1981). Thus, spills lead to the gradual poisoning of the water and the destruction of vegetation and agricultural lands. Oil companies usually attribute the cause of the oil spills to the deliberate action of sabotage, namely, willful damage to facilities by the local people in protest against the operations of the oil companies. However, in reality, the cause may be due to the use of decrepit pipelines, some reportedly over 40 years old, which crises-cross oil communities. These pipelines are rusty, obsolete, and poorly maintained. Consequently, on-site oil leaks and ruptured pipelines are a serious problem in the Niger Delta. In addition, oil spills and pipeline fires are regular features and official estimates are that there are at least 300 incidents each year. Clearing of oil spillages is not properly carried out; in most cases, the remaining crude oil is set on fire in which case forests and rivers are set ablaze. Oil spillage has exposed local people to severe hardship, poisoned the land, and polluted water bodies because once a spill occurs, it spreads all over the area, damaging the water and killing aquatic life. In other words, spills and leaks not only pollute groundwater sources and destroy agricultural lands and fisheries, they also pose an immediate threat to human life. HRW (1999) examine the longterm effect of oil spillage, which caused major pollution and stated that while the estimated safe lifespan of a pipeline is fifteen years, in numerous places in the Niger Delta, pipelines aged twenty or twenty-five years can be found.

According to the official estimates of the Nigerian National Petroleum Corporation (NNPC), based on the quantities reported be operating companies, approximately 2,300 cubic meters of oil are spilled in 3000 separate incidents annually. It can be safely assumed that, due to under-reporting, the real figure is substantially higher; conservative estimate place it at up to ten times higher. Another calculation, based on oil industry sources, estimate that more than 1.07 million barrels (45 million U.S gallons) of oil were spilled in Nigeria 1960 to 1997. (White Paper Series, 1997). Nigeria's largest spill was an offshore well blowout in January 1980, when at least 200,000 barrels of oil (8.4 million U.S gallons), according to oil industry sources, spewed into the Atlantic Ocean from a Texaco facility and destroyed 340 
hectares of mangroves. (Intelligence Report, 2000).

The effect of spill on land and water cannot be emphasized. For example, the effect on the environment of the contaminated "formation water" (also known as "produced water" separated from the hydrocarbon fluids with which it is mixed underground and deliberately discharged from flow stations and terminals is largely unevaluated. Formation water in some cases treated to remove residual oil, but in other cases released directly into the environment. While the water discharged generally contains low concentrations of oil, its large volume, together with occasional oil spillages, could well have long effects, depending partially on the ecological setting in which the discharge is made. In offshore locations or in areas with rapid drainage increased dilution reduces the polluting effects of water; on land and in the swamp; however, the cumulative effect "can be devastating at some location". Whatever the long term impact on the environment, spills can be devastating for those directly affected, especially in the dry land or fresh water swamp areas, where the effects are concentrated in particular locations. Oil leaks are usually from high pressure pipelines, and therefore spurt out over a wide area, destroying crops, artificial fishponds used for fish farming, "economic trees" that is, economically valuable trees, including those growing "wild' but owned by particular families and other income generating assets. Even a small leak can wipe out a year's food supply for a family, from which it wiping out income from product sold for cash. Mobil's Idaho blows in January 1999 resulted in the spilling of 40,000 barrels of oil. Although it was considered small, the spill spread from the immediate environment in Akwa-Ibom State to Rivers, Cross-Rivers, Edo, Delta and Ondo States. It even spread 85 kilometres into the Atlantic Ocean, going as far as Benin, Togo, and Ghana (Aworawo, 1999).

Field observations by the researchers revealed sites of oil spillage in certain communities, which turned the water brackish in colour. Generally, the people complained about the negative environmental effect arising from the incidence of oil spillage. The long-term environmental effect as highlighted by the local communities ranged from the depletion of aquatic or groundwater resources to the destruction of forests and mangrove swamps. The people also complained about the devastating impact of spills on all the communities. According to one community leader, an oil spill that occurred on 1st August, 2004 at Chevron's Ewan oil field spread to several neighbouring oil-bearing communities of Igo, Awoye, Odun-Oyinbo, Ubale Kekere, Ogungbeje, and Yoren, destroying fishing grounds, the major source of income for the people. However, the main cause of the spill could not be ascertained. Incessant oil spills have always been a source of agitation and concern in the oil-producing communities.

Empirical investigation on the implication of oil industry activities on peasant agriculture by Gbadegesin (1998) revealed that apart from loss of farms, oil spills have led to extensive deforestation with no adequate replanting practices. This has shortened fallow periods, compounded land use degradation and led to loss of soil fertility and consequently erosion of the top soil. In addition, there is drastic fall in output of the agricultural product which has led to intensive exploitation of other fertile land. This situation continues to reduce the land available for farming, thereby, creating unhealthy rivalry between the inhabitants and intolerable competition for available land space, further heightening cases of land related conflicts. This ultimately affected peasant agriculture in a variety of ways, causing problems of environmental refugees. It can be argued that the landless peasants who have been forced from their lands increases the numbers of people pursuing such a subsistence life style.

This contributes to deforestation through further encroachment on forestlands and reduction in fallow period. Some of the landless farmers migrate to other more fertile lands; while some of the displaced farmers out-migrate to the urban areas in search other means of livelihood (Elliot, 1998). Consequently, anger at the inequities felt by the affected communities had led to increase in the number of people posting protest against the loss of their lands, at the same time agitating against the poor exploitation of what they see as their oil even though, the constitution provides that oil is owned by the Federal government without benefit to them or compensation done to their land and their livelihood. Onosode (2003) buttressed this argument when he examined the general increased of oil and gas exploitation induced conflict in the Niger Delta. To him, "the intensity of these conflicts and the growth of environmental concern, all of which are linked to the politics of resources rampage and degradation and socio-economic, cultural and psychological dislocation in the Delta have raised both local and international interest"

A delicate balance according to Bisina,(2006) exist between the human population and its fragile ecosystem. Bisina, like other scholars' on the issues of environment held the view that, there is a strong feeling in the region, and that the rate of environmental degradation is pushing the region towards ecological disaster. It is the process of interaction between the two, plus the mediating role of the Nigerian state in the uncontrolled commercialization of natural resources without corresponding improvement in the living standards of the people, particularly the inhabitants of the oil producing areas, that have contributed significantly to the occurrence of conflict and violence in the region. It has been argued that by destroying the environment, man destroys himself and this directly or indirectly led to conflict between men and even with his environment. One of the basic premises of sustainable development therefore is the recognition that environment 
and development are not in the long run mutually reinforcing.

\subsection{Gas Flaring}

Similar to oil spillage is gas flaring; Nigeria flares more gas than any other country in the world. Approximately $75 \%$ of total gas production in Nigeria is flared, and about 95\% of the "associated gas" which is produced is the by- products of crude oil extraction from reservoirs in which oil and gas are mixed. The flaring in Nigeria has been reported to have contributed a measurable percentage of the world's total emissions of greenhouse gasses; due to the low efficiency of many of the flares much of the gas is released as methane which has a high warming potential, rather than carbon dioxide (World Bank Report). The percentage of gas flared in Nigeria, which is about three times the OPEC average, is about 16 times the world average (Ajayi and Ikporukpo, 2005).

Gas flaring is the deliberate burning of natural gas that is produced in the Niger Delta; it creates a ceaseless, high intensity flame. Natural gas is a by-product of oil extraction, which is removed from the earth crust along with the crude oil. The World Bank (1995) shows that gas flaring has been known to be the singular highest contributor to the problem of global warming or global climate change. In the same vein, Orubu (1999) adds that that greenhouse gases such as methane and carbon dioxide emitted from gas flares contribute to global warming, which could lead to a rise in sea level, accelerate the problem of climatic change and harsh living conditions on earth if not checked. It also has negative effects on the immediate environment as it adversely affects plant growth, wildlife, and human beings.

Compounding the people's plight is the close proximity of gas flares to residential areas, forests, and waterways, thereby making living unbearable to human beings, terrestrial and aquatic animals. At the mouth of the canal, from which the open sea is visible from the Awoye community, the distant gas flare illuminates Chevron's Parabe platform, which is nine kilometres away, and the Ewan platform about two kilometres. Specifically, due to the low efficiency of many of the flares, much of the gas is released as methane (which has a high warming potential) rather than carbon dioxide. At the local level, the low-lying Niger Delta is particularly vulnerable to the potential effects of sea level rising. Further, air and leaf temperatures increased up to eighty or one hundred meters from the stack, such that species compositions of vegetation are affected.

The most noticeable effect of the flares is light pollution. Across the oil communities, the night sky is lit up by flares, which during the rainy season reflect brightly from the clouds. It is difficult to differentiate between night and day because of the polluted air and burning light. Communities close to flares complain that the light disturbs nocturnal animals, driving them away from the area. The economic and health cost of heat emissions from the flares and destruction of vegetation are part of the negative externalities of the wasteful flaring of oil-associated gas. Indeed, gas flaring has been identified as the major cause of respiratory infection among the Niger Delta people, as well as the cause of reduced growth potentials of farm crops (Egwaikhide and Aregbeyen, 1999). Though economically sensible for the oil producers, flaring is environmentally destructive. Local communities have borne the brunt of the effects of the gas flares. The destructive impact of gas flares is succinctly expressed in the statement of one community youth leader who stated that the roofs of their houses have been severely corroded as a result of acid rain caused by gas flares, which also affects aquatic fauna leading to a reduction in fishery.

Ibeanu (2000) indicates that Nigeria exceeded the world average for natural gas flaring by seventy-two percent in 1991. In that year, while the world average for gas flared as a percentage of total production was four percent, Nigeria flared seventy-six percent of that total production. Flaring of gas in Nigeria for about 50 years has also been estimated to constitute a waste of 12.5 million dollars annually, an amount that would have been earned if the oil-associated natural gas was captured, sold, or used as a local energy source. However, the lack of delivery and utilization of infrastructure for natural gas in Nigeria render it a useless by-product (Onosode, 2003). Nigeria is not just number one; rather, it flares more gas than all the other eight countries put together. Although, with the gas utilization programme, the flare rate is said to have been reduced to about $54 \%$, the proportion flared is still very significant in global terms. Okonta and Douglas (2001) corroborated this and identified the reason for the high rate of gas flares in Nigeria as multinationals involved in oil exploration and production activities in Nigeria flared more gases in the course of their operation than in any other countries where they are involved in oil activities. They suggest that these oil companies found it economically expedient to flare non-associated gas on site rather than incur the expenses of putting in place facilities to re-inject the gas back into the wells or to collect it for commercial use.

One study of flares in the Niger Delta found that air leafs and soil temperature was increased up to eighty or one hundred meters from the stack, and species composition of vegetation was affected in the same area (Augustine, 1998). The end result of most of these experiences has always been conflict between the affected and whose is considered as 
the victim of the havoc. Whereas, this flair gas can be reduced or make use for domestic purpose as means of sustainability rather than flaring out. This however will entail much commitment from the Nigerian government. Focusing on the Federal government management of the environmental effect of oil production on the oil producing communities in Nigeria, Isumonah (2003) posited that government was extremely permissive of environmental degradation through the gas flaring and sluggish in enforcing environmental protection law but, rather, left environmental protection to the oil companies which could not be trusted to do the right things against realizing profit motive at the barest cost of production.

\subsection{Drill Cuttings}

Oil extraction and production lead to the contamination of streams and rivers through the discharge of various materials into the environment during drill cuttings and drilling mud and fluids used for stimulating production. The major constituents of drill cuttings, such as barite and bentonite clays, when dumped on the ground, prevent local plant growth until natural processes lead to the development of new topsoil. In water, these materials disperse and sink, thereby suffocating local bottom-living plants and animals by burying them (ANEEJ, 2004). In addition, air pollution arises during drill cutting from the carbon dioxide discharged into the atmosphere as a result of the cracking of wells (Adewuyi, 2001). CRP (1999) identifies the chemicals and sludge generated in the oil production process to include oily residues, tank bottom sludge, and obsolete chemicals, which, if not properly treated and disposed of, carry high pollution and health risks. Van Dissel (1996), cited in HRW (1999) explains that waste also comes in the form of drilling water. Drilling for oil produces waste, largely mud, which in itself is relatively harmless, but when produced in large quantities can cause problems by changing the acidity or salinity levels of the soil and/or water and by increasing the turbidity of the water. Therefore, the physical environment is altered in the course of oil wells drilling and vegetation is destroyed.

\subsection{Canalisation}

Poorly designed causeways and canals, constructed to bring in heavy drilling equipment, affect the hydrology of the seasonally flooded fresh water swamps and the brackish water of the mangrove forest. Canals disrupt the delicate hydrological system, especially when they are constructed on the border zone between freshwater and brackish water in the riverine areas; as such, they can disrupt the viability of long-established fishing grounds.

\subsection{Dredging}

This is another environmental effect of oil exploitation in the oil communities. Dredging destroys the ecology of the dredged area where the spoils are dumped. Although dredged material is, in principle, dumped on land, some of it inevitably washes back into the water, thereby increasing its turbidity and reducing sunlight penetration, which affects plant life and kills fish in the creeks and rivers. Dredged materials in mangrove areas turns acidic once exposed to oxygen and silt dredged as a result of canalization and dumped on cultivated leaves can decrease farm yields.

\subsection{Coastal Erosion}

Coastal erosion affects artificially all the oil communities of the Niger Delta bordering the Atlantic Ocean. The Ilaje oilbearing areas in Ondo states are no exception as part of Southern area of Niger Delta. UNDP (2006) attributed this erosion as partly the result of rising sea levels and strong tidal wave current. Oil and gas activities have also contributed to the increasing menace of erosion through the construction of canals, shore crossing, pipelines, jetties, and moles. The sea waves break on the shore; land is erodes and washes into the sea. Coastal erosion has become a constant threat to many oil-bearing communities of llaje beginning as far back as 1988. The African Guardian, reports that erosion has laid waste to some coastal communities such destruction has affected riverine communities such as Awoye, Ojumole, Umohuma, Ikorigbo, Jirinwo, Molutehin and Ogungbeje (The African Guardian, January, 1988).

In recent times, Chevron's seismic activities have left the oil communities in the state porous, leading to the threat of sea incursion. Awoye and Ayetoro are seriously threatened by sea incursion. In Awoye, for instance, the earliest site is now some two kilometres into the ocean, an indication that the community is threatened by tidal incursion. One coastal community leader lamented the hardships faced as a result of tidal incursion. According to him, since Chevron, formerly Gulf Oil, started operation in llaje, the riverbed has turned to rivers and sea incursion has become a constant threat. As a result of the encroachment of the ocean, for example, one coastal community is now found at its 6th relocation site. In 
the case of another coastal town, which until recently comprised a convergence of fishermen and women whose trade attracted patrons from the upland and beyond, sea incursion is a reality that threatens their continued existence.

\subsection{Effluent and Waste from Oil Refineries}

The discharge of refinery effluents into freshwater sources and farmland devastate the environment and threaten human lives. Such effluents contain excessive quantities of toxic materials like mercury and chromium. For instance, fish can store mercury in their brains for a long time and can easily pass this into the human food chain when consumed resulting in adverse effects on human population. Recent studies conducted by the environment group, Environmental Rights Action (ERA, 2000), on some oil-bearing communities revealed that most of the underground aquifers are heavily contaminated with a cocktail of dangerous metal and chemicals.

Crude oil contains thousands of different chemicals, many of which are toxic and are known to be carcinogenic with no determined safe threshold for human exposure (HRW, 1999). Further, materials such as metals, glass, plastic, and crates used by the oil companies, which are later thrown away, have a negative effect on the people and environment. Atmospheric contaminants from refinery operations, such as oxide of nitrogen, carbon, and sulphur have been found to constitute major waste sources. Lubrication oils and other wastes in the form of sludge, bitumen, slope, and oil, sand, or sediment are present in large quantities within the oil flow stations, storage terminals and tanks (Nwakwo and Ifeadi, 1988). Chemical wastes are continuously dumped into the waterways, although the oil companies claim to technically reduce the toxicity of their wastes and properly get rid of them. In one community, the people showed the researcher sites of oil wastes in the water by the riverbanks, which has turned blackish and emits odour. Gberesu (1989) opines that a high rate of disposal of fluids from the petroleum industry into the river is responsible for the increased floods experienced in the Niger Delta because the disposal has increased the viscosity of the river thereby reducing velocity.

Oil companies usually discharge production water, already contaminated with oil, directly into the surrounding creeks and rivers without adequate treatment. Sludge and other lethal chemicals removed from the bottom of storage tanks in the course of maintenance activities are disposed of in the same way (Okonta and Douglas, 2001). Oil leaks from storage tanks and equipment are also a regular phenomenon and these, combined with hydrocarbon vapour released and evaporated directly from the tanks themselves, have subjected the soil, rivers, and creeks in the vicinity of the oil terminals to slow but relentless devastation. However, evidence indicates that even though the Nigerian government and oil companies are aware of these negative environmental effects of oil exploitation, they have not made any concerted effort to control the adverse effects of oil extraction, production, and distribution activities on the environment of the host communities.

\section{Conclusion}

An important conclusion of this discourse is that environmental negligence fostered disillusion of communities of oil bearing areas with oil exploitation and they were also embittered by denial of recognition of their region as the source of wealth that sustains the country. So the persistent agitation for resources control in Nigeria analyzed the minority question as indicated by national ruling class to contend with environmentalist groups apart from militant action which could effectively mobilized the people against the pollution of their environment by oil companies. As Obi (2002) have opined, except the ethnic minorities from whom this wealth resources and our economic base are made to have sense of belonging to the "new national bargain," given equal access and rights to opportunities within a democratized socioeconomic and political order, the nation state project in Nigeria would remain in a state of crisis and the grim possibility of break up. However, ability to manage this endowment in the positive way with our consciousness to our environment will make live better than how it is today in Nigeria.

For example if we could make use of the gas for more domestic purpose Nigerian are going to have great relieve of expensive price pay to get kerosene and scarcity of same product. Likewise, good utilization and extended energy service can turn around our economy as this is going to generate increase employment and income opportunities for all, and therefore make a pre-requisite to increase value adding activities in our rural areas. Access to energy is a curcial enabling condition for achieving sustainable development. Prudent energy policies and research can therefore, play an important role steering both industrialized and developing countries onto more sustainable energy development paths specifically, they can strengthen the three pillars of sustainable development: the economy, by boosting productivity; social welfare, by improving living standard and enhancing security and the environment, by reducing indoor and outdoor 
pollution and remediating environmental degradation. For instance, U.N Human Development index provides insight into this important correlation, showing that the increased use of energy and electricity is a perquisite for economic development and improved quality of life, particularly for developing countries. Our challenge therefore become how we can use energy more efficient with reduce environmental impact, while maintain economic growth and prosperity.

Our policy makers should help us in creating a sustainable energy pathway which will require broad societal consensus around the strategic choice of economic, environmental and social development. This is important and should be made a priority in the current development of our discourse in this gathering that a country likes Nigeria will likely need to pursue different paths towards a variety of sustainable development options as regards to available natural endowment in our land. We will require different policy mixes, likely incorporating fiscal, regulating and research and development efforts. For better planning, following priority for energy policy planning is important.

- Expanding electricity generation through centralized and decentralized system using conventional or renewable energy based on the resources available domestically.

- Expand access to modern and cleaner fuels, including liquefied petroleum gas, in rural areas through public private collaboration to provide affordable alternative to tradition fuel use for household and industry application.

- Energy efficiency which relate to essential use of less energy to provide the same service. In this sense, energy efficiency is thought of a supply resource-often considered as important, cost effective investments which can provide additional economic value by preserving the resources based of our oil, and especially combine with pollution prevention technologies mitigating environmental problems.

- Improvements in energy efficiency can produce direct environmental benefits in a number of wings not only reducing oil pollution, but also delaying the need to develop new fuel resources. In addition, energy efficiency improvement can considerably reduce the cost of pollution abatement.

- Improve energy can as well sustain our energy consumption rate. For example, investing advance technology can help us to meet with our growing demand in energy consumption, availability of affordable energy products, while improving security of supply and reducing environmental impacts.

Conclusively, if our policy makers could enforce their legislative authority on some of these above mentioned ideas, it is believe that this will enhance our contribution to sustainable development through a greater integration of economic, environmental and social dimensions. Also there shall be continuous availability of affordable secure environmental sound and social acceptable energy products and services for growing world population. It will definitely, improve our social dimension of business and broaden the benefit of wealth creation and thereby contribute to the alleviation of poverty in our country.

\section{References}

Abiodun, A. 2007. Resources Conflict in African Countries: The Tragedy of Natural Endowment. Woodbridge, Suffolk Rochester Press. Adewuyi, A.O. 2001 "The Implication of Crude oil Exploration and Export on the Environment, and Level of Economic Growth and Development in Nigeria". A paper presented at Nigerian Economic Society Annual Conference.

Aworawo, D. 2004 Fiscal Allocation and Development at the Third Tier in the Constitution. Journal of constitutional development. Center for Constitutionalism and Demilitarization.

Brennan Scott and Jay Withgott, 2005. Environment: The Science behind the Stories. San Francisco: Person Education.

Energy Compass, 1998, Vol 9, No 41.

Ernest, H. 2007. "Conflict resources: from 'curse' to blessing". Africa Renewal Vol 20 pg 17.

Eteng, I.A. 1998. The Niger Delta, oil exploration and community interests, "Issues and prospective" In Adewunmi F ed 1998. Oil exploration, and the State and Crisis in Nigeria's Oil bearing enclave. Lagos: Fredric Ebert foundation.

Eteng, I.A 1998. The Nigeria State, Oil Exploration and community interests issues and perspectives. Funmi Adewunmi (ed) Oil Exploration and Exploitation, the state and crisis in Nigeria's oil Bearing Enclave. Lagos: Fredric Ebert foundation.

Gbadegesin, A. 1998. "Impact of oil Exploration and Production Activities on the Environmental: Implication for Peasant Agriculture" In Adewumi F .ed 1998. Oil exploration, the State and crisis in Nigeria's Oil bearing enclave. Lagos: Fredric Ebert Foundation.

Horsnell,P.2005.EnergySecurity-http:www.iags.org/es040403.html. htt:/www.ctfr,org.etfrn/newsletter/news. Accessed on 21 st, June 2010 Hudson, H.1969. Resource-based Conflict:Water Insecurity and its Strategic Implications. Htt://www.hrw.org/reports/1999/nigeria2. Accessed on 21 st, June 2010.

Ibeanu, O. 2000. 'Oiling the friction: Environmental Conflict management in the Niger Delta, Nigeria.' Environmental Chang and Security Project Report, Washington DC; The Woodrow Wilson Center, No.6 P 19-32

Imobighe, Ronald and Baker, 2002. Conflict and Instability in the Niger Delta: The Warri Case: Spectrum Book Ltd.

Judith Rees, 1994 National resources: Allocation, Economics and policy. London: Routledge. 
Khan, 1976, Nigeria Table 8.3 World Bank, World Bank Development Report.

Klare, M. 2001, Resource Wars-The new landscape of global conflict. New York: Henry Holt publisher.

Ohiorhemuan, J.F 1998. Capital and the State in Nigeria. New York: Greenwood press.

Okonta, I. and Douglas, O. 2001 Where Vulture Feast: Forty Years of Shell in Niger Delta. Benin: ERA/FOEN.

Onosode, G. 2003, Environmental Issues and the Challenges of the Niger Delta; Perspectives from the Niger Delta. Environmental Survey Process, Yaba: The CIBN Press Limited.

Orubu, C.O. 1999, The Exploitation of Non-Timber Forest Resources in the Niger Delta: Problems and Perspectives. Technical paper, Niger Delta Environmental Survey, Port Harcourt.

Orubu, C.O., Odusola, A. and Ehwarieme, W. 2004. The Nigerian Oil Industry: Environmental Diseconomies, Management Strategies and the Need for Community Involvement, Humanities and Ecological, Vol. 16 No 3: 203 - 214.

Scott R. Pearson, 1970, Petroleum and the Nigeria Economy. Stanford University of California Press

Ukeje, C, Odebuyi, A., Sesay, A.and Aina, O. 2002. Oil and Violent Conflicts in the Niger Delta. CEDCOMS Monograph Series No 1, IleIfe: Centre for Development and Conflict Management Studies.

UNDP 2006. Niger Delta Human Development Report Garki, Abuja: UN House.

Vandama S. 1995 "Resources," in the development Dictionary, ed. Wolfgang Sachs. London: Zed Books Ltd, p.206.

World Bank 1995. Defining an Environmental Development Strategy for the Niger Vol.2, Washington D.C.

World Bank 2000/2001. World Development Report. Washington D.C.

Wolf-Christian, P. 2004. Oil Production and National Security in Sub-Sahara Africa. In Rudold Traub-Merx Ed. Oil policy in the Gulf of Guinea: Security and Conflict, Economics Growth, Social development

Simmons, 1974. The Ecology of Natural Resources. London: Edward Arnold, p.3. 